\title{
ASYMMETRIC INFORMATION AND HEALTH-RISK BEHAVIOR IN THE NATIONAL HEALTH INSURANCE SCHEME IN JOS METROPOLIS, NIGERIA
}

\author{
Joshua Solomon Adeyele ${ }^{1 *}$, Gbenga Michael Ogungbenle ${ }^{1}$ and \\ Ogorchukwu Augustine Isimoya ${ }^{2}$ \\ 'Department of Actuarial Science, University of Jos, Nigeria \\ 2Department of Actuarial Science and Insurance, University of Lagos, Lagos, Nigeria
}

\begin{abstract}
Access to quality healthcare is the primary purpose for which the National Health Insurance Scheme (NHIS) in Nigeria was introduced. It is believed that the introduction of the NHIS for workers will reduce their engagement in health-risk behavior. Despite the existence of the NHIS, its enrollees (i.e. insured workers) are still complaining of the poor healthcare delivery by the service providers. As a result, some of them are still engaging themselves in a detrimental health-risk behavior due to public health workers' moral hazard and a short supply of drugs in public hospitals. This study was undertaken in Jos metropolis so as to ascertain the extent to which moral hazard and the disclosure of partial information about the NHIS lead to a health-risk behavior among civil servants. The research has shown a moderate level of the moral hazard demonstrated by the NHIS service providers since, within the measurement range from 1 to 7, the overall average significantly falls to 4 . Contrary to the moderate moral hazard demonstrated by the NHIS service providers, the majority of the NHIS enrollees were found to averagely demonstrate a low health-risk behavior.
\end{abstract}

Keywords: NHIS service providers, moral hazard, asymmetric information, health-risk behavior

JEL Classification: D82, |11, |13

\section{INTRODUCTION}

Civil service is often associated with a poor service delivery because of the assumption that whether civil servants do well on the job or not, they will still

* Correspondence to: J. S. Adeyele, Department of Actuarial Science, University of Jos, Nigeria;

e-mail:adesolojosh@gmail.com receive their salaries. This assumption has made some civil servants demonstrate a nonchalant attitude towards a quality service delivery in their place of work. For many years, civil service in Nigeria has been characterized by poor performance. Countries around the world have carried out reforms in civil service in order to improve the quality of the public service delivery. However, while demand for improved services is a common factor, the spectrum 
of expectations varies from one country to another. In Nigeria today, things are expected to work well in the health sector, just like in other developed countries in the world.

As one of vital tools available to human societies in the $21^{\text {st }}$ century for achieving economic goals (Berman, Pallas, Smith, Curry \& Bradley, 2011), the health system requires continuous research in order to determine how it affects patients' satisfaction. In other words, the satisfaction of patients is seen as a critical indicator of the quality of healthcare (Laschinger, Hall, Pedersen \& Almost, 2005) and has been viewed as an integral ingredient for measuring the health outcome and the quality of care all over the world.

Prior to the introduction of the National Health Insurance Scheme (NHIS) in Nigeria, the health insurance contract had depended on copayments and deductibles used to reduce health consumption amongst the insured public. According to M. C. Albert and M. H. Riordan (2002), these control instruments force the insured to reduce their demand for expensive healthcare, thereby taking advantage of low premiums. This restriction, however, exposes healthcare seekers at large to uninsured risks. On the other hand, the introduction of the NHIS empowers accredited hospitals as service providers to give specific treatment and limit expensive treatment to all enrollees.

The NHIS was established in Nigeria primarily in order to make healthcare accessible to all the Nigerians at an affordable cost. Contrary to this expectation of the scheme, some workers do not receive correct treatment as they are not attended to when visiting hospitals. One of the reasons why some insured workers cannot access the NHIS scheme is partly due to the misplacement of their records by health workers and partly due to long queues, with but few health workers who need to attend to patients. The extent of the moral hazard demonstrated by healthcare providers with a larger number of clients and equipped with the facilities and the manpower in place to do the job gainfully accounts for the reasons for long queues experienced in the NHIS accredited hospitals.
Where insured workers are unable to access their NHIS scheme, they attempt to minimize the cost of health and sometimes engage in unethical healthrisk practices endangering their own lives. Where a particular service has been promised, but not delivered due to an inadequate facility in place to meet such needs, that leads to dissatisfaction among enrollees. Healthcare personnel often allege that capitation is not made available by the Health Maintenance Organization (HMO), which receives the bulk of capital from the government or employers. This also suggests that moral hazard is demonstrated by the service providers that tend to meet minimum requirements for the accreditation of their hospitals, but there is no demonstration of the professional responsibility to match the competence and an expectation beyond this limit. These trends have led to the two main issues: the first, asymmetric information about NHIS services available to those insured workers, and the second, moral hazards among NHIS primary healthcare providers in public hospitals. Not many studies on the NHIS in Nigeria have considered these two important variables in the health sector. Consequently, the present study attempts to investigate whether moral hazard and asymmetric information are present in the selected NHIS hospitals in Jos metropolis or not. The study has the following specific objectives: to determine the effect of healthcare providers' moral hazard on the NHIS enrollees' health-risk behavior; and to examine the effect of asymmetric information on enrollees' health-risk behavior. The hypotheses to be tested include the following:

H1: Healthcare providers' moral hazard does not have any significant effect on the NHIS enrollees' health-risk behavior.

H2: Healthcare providers' asymmetric information does not have any significant impact on the NHIS enrollees' health-risk behavior.

The scope of the study is restricted to the outpatients who visit hospitals for the examination and medication purposes. The patients who have already been admitted to the hospital facilities are excluded from this study. The study does not extend to the 
organizations in the public and the private sectors that are yet to be accredited by the NHIS, either. The outcome of the study will help healthcare providers manage and reduce long queues in their organizations. This will, in turn, reduce enrollees' worries and their involvement in health-risk behavior, too. Also, it will help the government to achieve the objectives set out for the NHIS in Nigeria.

\section{LITERATURE REVIEW}

The characteristics of the healthcare service such as monopoly, ethical concerns, and asymmetric information such as adverse selection or moral hazard influence the healthcare delivery (Carlstrom, 1994). Healthcare economists prove that, due to these characteristics, organized private competitive markets are inefficient when the provision of healthcare services is concerned although many nonmarket institutions and the official interventionist approach have been arranged so as to remediate the alleged market failures. S. Shmanske (1996) observes a kind of information asymmetry that exists in a situation when a medical doctor has a prior knowledge that is not available to the patient. In order to save patients from quacks, governments impose licensing provisions in order to control medical associations. It is observed that many of the alleged market declines in the provision of health services rarely elicit economic scarcity and are consequently treated best by market institutions, but not government interventions.

A critical assumption of a perfectly competitive model is that both buyers and sellers are well informed. As a matter of fact, insurance is a complex business, with neither buyers nor sellers appearing to have as much information as they need. An information imbalance creates hydra-headed problems in insurance and undoubtedly the industry's most critical market imperfections (Black \& Skipper, 2000). The two major information problems are the problems of asymmetric information and nonexistent information. According to U. Black and H. D. Skipper (2000), the asymmetric information problems which drive the largest number of the insurer's operations arise where one party to an insurance contract has the relevant information that the other does not have, and also are the bane of the majority of life and health insurance customers.

Basically, there are four classes of asymmetric information. There are lemons, moral hazard, adverse selection and the principal-agent. However, the first two are used in this study as they relate to the NHIS service providers. "Lemons" in health economics is used to describe a situation where policyholders know less than insurers and their offerings. An insurance transaction is a contract including the current present promise of future performance following the occurrence of insured events. Although efforts have been made to simplify insurance contracts and enhance their readability, life and health insurance contracts remain technically complex documents (Black \& Skipper, 2000).

Individuals buy insurance policies in good faith by relying on insurers' integrity to honor their contract in the future, when insured events occur. Even if it is assumed that policyholders could be influenced to take an interest in the financial condition of their insurers, few of them are knowledgeable enough of how to do so. The lemons problem for policyholders provides a justification for many insurance regulations. Insurance companies, as well as their representatives, have insignificant incentives when the disclosure of adverse information to potential policyholders is concerned. On the other hand, the moral hazard problem is the tendency of individuals to alter their behavior because of the subsisting insurance.

Moral hazard problems are concerned with both life and health insurance, but the nature of problems differs to some extent. Life offices are not overly bothered about a possibility that the insured possessing a life insurance coverage will engage themselves in a behavior that could shorten their lifespan just because they are insured. Neither are they particularly concerned about the possibility that those who purchase life annuities will engage themselves in a behavior implying the elongation of their lifespans just because of the fact that they own such annuities. For most of us, the desire to continue 
living is not influenced by whether we are insured or not. Moreover, insurance companies are greatly concerned about the possibility that the beneficiary under a life insurance policy might try to shorten the life of the person insured. They are also greatly concerned about the selling of a disability income policy whose benefit payment would provide more than the insured could earn from employment. Doing so would mean that the insurance company itself has provided an incentive for the insured to try to collect the benefit. It would create moral hazard (Black \& Skipper, 2000)

Moral hazard was adopted in the health economic literature in the 1960's in order to describe the difficulty of contracting overusing healthcare as a result of the insured paying less than the service rendered by a healthcare provider (Zeckhauser, 1970). The main aim of health insurance is to distribute a risk of incurring high medical costs. The authors observed that the provision of insurance introduces uncontrollable incentives towards over-expenditure if, as is usually the case: the insured has control over the circumstance, and the level of being recompensated by the insurance plan is a positively related function of the expenses incurred by the insured. Moral hazard refers to the possibility of the insurance protection to alter an individual's behavior so as to present a loss (Shavell, 1979).

In the context of health insurance, moral hazard is seen as additional healthcare used as a result of the availability of the insurance scheme in place for the insured. At this point, there is a need to differentiate between ex post moral hazard and ex ante moral hazard in order to appreciate how they manifest in a long-term care insurance context. According to R. T. Konetzka, D. He, J. Guo and J. A. Nyman (2019), ex ante moral hazard refers to an increased possibility that a person will become sufficiently ill or dependent to be eligible for a payment under the policy because he/she has insurance, whereas ex post moral hazard is the type that is most often associated with health insurance and refers to the increased consumption of long-term care services by those who are eligible for a payment relative to those who are not (Konetzka et al, 2019).
In the long-term care context, it is clear that ex post moral hazard will be demonstrated by the scheme holder who may likely spend more time in a nursing home or receive a formal home healthcare service in comparison with the one who does not have a health insurance coverage. Ex post moral hazard will also surface in the person who elects to receive care in a preferred setting since that person's preference has been broadened due to the availability of the insurance payoff (Konetzka et al, 2019). Growth in formal home healthcare, as compared to no care or care at home by informal caregivers, such as close relatives, or growth in private nursing home care in comparison to either medical aid nursing home care or the varieties of possibly informal care at home, is a good instance of this type of moral hazard.

Prior to the proliferation of managed care, the health insurance scheme significantly relied on deductibles, copayments and other coverage limitations to manage care provision. These "demand management" tools cause the insured to limit their demand for healthcare and hence review downward premiums by restraining healthcare costs, on the one hand, but on the other, they may expose enrollees to a severe uninsured peril (Albert \& Riordan, 2002). However, managed care plans encourage healthcare providers with explicit financial incentives, such as prospective payments, remuneration for healthcare providers, where providers enroll patients as permanent clients, receiving a periodic payment on each enrollee and cost sharing contracts to limit costly treatments. Clearly, these "supply management" tools are now more important. Economic theory interprets the emergence of institutions as a response to market failures (Albert \& Riordan, 2002).

In the health industry, the market's poor performance derives from the problems of contracting illness $e x$ ante. Because of this failure, real insurance, which protects enrollees from the expenditures of efficientlyprovided treatment, does not seem to be possible. The second-best insurance pays only part of the treatment expenses or limits coverage in other ways (Albert \& Riordan, 2002). However, the patients who do not fully bear the cost of medical care may demand treatment inefficiently since the cost of treatment at times is more 
than the benefit (Albert \& Riordan, 2002). This failure is known as moral hazard. Also, in health insurance markets, when an underwriter acting as a third party pays for the service received by the patient, moral hazard may arise. Patients tend to continue to enjoy services when an additional cost incurred is much greater than the additional service they are enjoying. When a third party either partially or fully bears the cost of additional care, the client may request more care than he/she would demand if he/she bore all of the costs on his/her own. In mathematical econometric analysis, the overconsumption of healthcare service results in a shift down the demand curve to a quantity higher than that corresponding to the equality of the demand cost and the marginal price.

The gross inefficient overconsumption of health services constitutes a problem. In view of $S$. Shmanske (1996), moral hazard represents the inequities of commission and the transgressions of omission. Moral hazard may occur if the insured bearing a partial or not bearing any marginal cost of services intentionally embarks on unhealthful risk behavior. The health of the insured deteriorates and, consequently, the insured requests more healthcare.

S. Shmanske (1996) argues that increased healthcare costs borne by a third-party payer will be borne by the insured in the form of taxation or an insurance premium in the end. An incentive to limit a request for healthcare service can restore the system when the underwriter reviews premiums upwards in order to force high-volume consumers to bear an additional cost of medical care. Cautionary measures, though, which will enhance efficiency are also meant to force an insured to avoid the inequity of commission and omission, and stop consuming alcohol if the value of the premium decline seems to be higher than the forgone alternatives. When the premium cost is set at an average cost or below it irrespective of the attitudes of the policy holder, then there is a tendency that cautionary measures will not be taken.

The condition of moral hazard will be severe when all policyholders are included in the same pool and every life is billed an average cost of cover. S. Shmanske (1996) believes that a market approach in solving a moral hazard problem is the establishment of a health maintenance organization where a third-party payer and the provider of healthcare services are one and the same entity. This approach is intended to monitor and forestall the overconsumption of healthcare services; however, a big issue here is observers' contrasting views since a medical doctor is he who dispenses healthcare and, simultaneously, is the residual claimant.

There is little legislation enacted to control the abuse of healthcare services and include, but not limit to, the prioritization of permissive procedures (Fox \& Leichter, 1991; Iversen, 1993). Dealing with the unbearable costs and overconsumption of healthcare services, but overlooking the issue of information asymmetry occurring between a sick person and a third-party payer, official interventions cover the problem of the economic scarcity that may both inhibit and delay an efficient understanding and solving of the problem. An uncivilized simple approach solution to moral hazard is to do away with third-party payers as the sick individuals who will bear the cost on their own; however, the approach may contrast with the desire of the insurance market to spread risks.

Naturally, people will not willingly bear the cost for their healthcare out of their own pocket due to the risk of the uncertainty of the amount of the cost of their healthcare and, consequently, an insurance cover will be requested so as to smoothen the expenses of the healthcare services. S. Shmanske (1996) assumes that market participants such as HMOs, copayments, and deductibles should make the arrangements that will reduce abuse emanating from moral hazard provided that expected gains outweigh expected costs. Despite the fact that the insurer may be eager to bear actual unexpected healthcare costs, the insurer is not obliged to pay for healthcare costs emanating from any abuse provoked by any payment arrangement. The health insurer and the policyholder request a risk transfer without the existence of any moral hazard; however, economic scarcity imposes an inherent cost on the insurer's part so as to differentiate between the expenses which are desirable and those which are undesirable in order to care for the insured; hence the inherent cost on the insured forces the insured to credibly avoid the abuse of services. 
J. R. Garven and M. F. Grace (2007) carried out a critical investigation posed by an adverse selection problem suggested by theoretical prediction and found out that the result was consistent with the theoretical projections of E. L. Jean-Baptiste and A. M. Santomero (2000). Nonetheless, each of these two works clearly focused on a part of the asymmetric information issue, simultaneously ignoring the existence and the effects of the other part. A critical assumption by N. A. Doherty and K. Smetters (2005) is that moral hazard remains a significant effect of the asymmetric information, whereas J. R. Garven and M. F. Grace (2007) concluded that adverse selection was the effect(s) of asymmetric information.

By linking asymmetric information and moral hazard in the context of health insurance to the NHIS, many studies have looked into how moral hazard by customers (insured patients) affects the performance of the NHIS. In this study, asymmetric information associated with NHIS services used by service providers in order for them to gain an undue advantage over the NHIS enrollees is considered as moral hazard. Although NHIS enrollees visit hospitals' different departments, there are a high percentage of outpatients referring to the NHIS for their needs pertaining to healthcare. Long queues affect a pharmacy's efficiency, which subsequently results in patients' dissatisfaction (Marquez-Peiro \& Perez-Peiro, 2008). The findings of a certain number of studies dedicated to the queueing system in the health sector indicate a strong relationship between patients' satisfaction and their satisfaction with respect to the drug services (Ndukwe, Omale \& Opanuga, 2011; AlArifi, 2012). However, accompanied by inadequate drugs and medical facilities of the largest number of the accredited hospitals, long queues have been brought into connection with health-risk behavior among the scheme users.

A. Steptoe and J. Wardle (2004) describe health-risk behavior as any human activity engaged in by people in the density or with the force that increases the chance of a risk of sickness or an injury. A. Baban and C. Craciun (2007) observes that health-risk behaviors can cluster together into a risky lifestyle. J. S. Adeyele
(2014) observed that many civil servants die due to a lack of access to good medical facilities. The author further noted that certain factors related to healthrisk behavior emanating from religion, culture and education had been attributed to sudden death among civil servants. In some studies it was discovered that health-risk behaviors could wield some level of influence on cognitive performance, emotions, and a quality lifestyle.

\section{METHODOLOGY}

The study population comprised all the public hospitals in North Central Nigeria. A questionnaire was used to collate data from the enrollees about the NHIS services and the possibility for any one of them to engage him-/herself in health-risk behavior if the services required are not readily available. The data were collected from the NHIS enrollees in public hospitals by obtaining a permission from the management of the selected hospitals. The simple random sampling technique was used to distribute 350 copies of the questionnaire to the respondents in five public hospitals located in Jos metropolis, of which 319 copies were completed and returned. The details of the selected hospitals, as well as the distribution of the respondents by the gender, are shown in Table 1.

Descriptive, correlation and multiple regression statistics were used to analyze the data collected. The criteria used to determine the level of information asymmetry (INFAS), moral hazard (MORHAZ) and health-risk behavior (HRBehv) amongst the primary healthcare providers and the enrollees range from 1 to 7 , namely as follows: $1=$ extremely low, $2=$ very low, $3=$ low, 4 = moderate, $5=$ high, $6=$ very high, and $7=$ extremely high. Based on this scale ranging from 1 to 7 , if the mean weight $(\mathrm{MW})>1.5$, it is means extremely low; if the mean weight is $1.5 \leq \mathrm{MW} \leq 2.49$, it means very low; if the mean weight is $2.5 \leq \mathrm{MW} \leq$ 3.49 it implies low; if the mean weight is $3.5 \leq \mathrm{MW} \leq$ 4.49 then it means moderate; if the mean weight is 4.5 $\leq \mathrm{MW} \leq 5.49$, then it means high; if the mean weight is 
$5.5 \leq \mathrm{MW} \leq 6.49$, it means it is very high, whereas if the mean weight $\mathrm{MW} \geq 6.5$, it means it is extremely high. These mean weights consisting of INFAS, MORHAZ and HRBehv in Tables 2, 3 and 4, respectively, were obtained by the application of the SPSS software.

Model Specification - In order to test the significance of the impact of asymmetry information and moral hazard by healthcare practitioners on the NHIS enrollees' health-risk behavior, multiple regression was used to jointly test the two hypotheses. The required testing model in order to achieve the specific objective of the study is formulated as follows:

$$
H R B e h v=\gamma_{0}+\gamma_{1} M O R H A Z+\gamma_{2} I N F A S+\varepsilon
$$

where:

\section{HRBehv - Health risk behaviour, \\ MORHAZ - Moral hazard, \\ INFAS - Information asymmetry.}

The coefficients of $\gamma_{1}$ and $\gamma_{2}$ are expected to be positive. Hence, it is expected that the model will exhibit health-risk behavior due to the presence of moral hazard and information asymmetry.

Table 1 The distribution of the NHIS primary healthcare provider by the enrollees' gender

\begin{tabular}{|c|c|c|c|}
\hline & \multicolumn{2}{|c|}{ Gender } & \multirow{2}{*}{ Tota } \\
\hline & Male & Female & \\
\hline Airforce Military Hospital & 19 & 31 & 50 \\
\hline Plateau Specialist Hospital & 17 & 49 & 66 \\
\hline $\begin{array}{l}\text { Jos University Teaching } \\
\text { Hospital }\end{array}$ & 47 & 73 & 120 \\
\hline $\begin{array}{l}\text { University of Jos Health } \\
\text { Centre }\end{array}$ & 24 & 19 & 43 \\
\hline General Hospital, Pankshin & 12 & 28 & 40 \\
\hline Total & 119 & 200 & 319 \\
\hline
\end{tabular}

Source: Authors

\section{RESULTS}

This study was carried out in public hospitals due to the observed moral hazard and the perceived information asymmetry. The descriptive results in terms of the disclosure of the information to customers, moral hazard and health-risk behavior are presented the first, only to be followed by the test of the hypotheses.

Table 2 shows the non-disclosure of information about the NHIS services in the public sectors. Out of the five criteria against which the nondisclosure of information was assessed, some respondents extremely disagreed, whereas the others extremely agreed with all of these items. As far as the first and the second criteria are concerned, many respondents were indifferent to whether the NHIS operators disclosed the services covered by their scheme to the enrollees until the enrollees needed such services or not (INFAS1: mean/std dev. $=4.2163 / 1.40314$, Coeff. of Var $=0.3327883, p<0.000)$, and the NHIS providers did not disclose the specific services excluded from the NHIS to enrollees (INFAS2: mean/std dev. = 4.2351/1.39334, Coeff. of Var $=0.3289981, \mathrm{p}<0.000$ ). Also, many respondents were indifferent as to whether the NHIS providers did disclose the risks covered by their scheme to them or not (INFAS3: mean/std dev. $=4.0313 / 1.48545$, Coeff. of Var $=0.3684747, \mathrm{p}<$ 0.000). Additionally, many respondents were neutral with respect to whether the NHIS enrollees were, or were not, educated on the need to get a referral form from their service provider whenever they need to refer to another hospital of their primary healthcare providers (INFA42: mean/std dev. $=3.8621 / 1.57209$, Coeff. of Var $=0.4070602, \mathrm{p}<0.000)$. The respondents could not ascertain, either, whether they were made to pay the full cost of the medical bills in the hospital they were being referred to, or not (INFAS5: mean/ std dev. $=4.0596 / 1.40738$, Coeff. of Var $=0.3466828$, $\mathrm{p}<0.000$ ). All of these responses to the criteria are significant and are brought into agreement with the overall weight of the measurement for the purpose of assessing the disclosure of information by the NHIS (INFAS: mean/std dev. $=4.0809 / 0.88202$, Coeff. of Var $=$ $0.2161359, \mathrm{p}<0.000$ ). Based on the respondents' score on the scale from 1 to 7 , it can be concluded that the 
Table 2 The disclosure of information to customers by the NHIS service providers

\begin{tabular}{|c|c|c|c|c|c|c|c|c|}
\hline CODES & $\begin{array}{l}\text { Criteria for } \\
\text { information disclosure }\end{array}$ & $\mathrm{N}$ & Mean & $\begin{array}{c}\text { Std. } \\
\text { Deviation }\end{array}$ & Minimum & Maximum & $\begin{array}{l}\text { Coeff. } \\
\text { Of Var }\end{array}$ & $\begin{array}{l}\text { Monte } \\
\text { Carlo Sig. }\end{array}$ \\
\hline INFAS1 & $\begin{array}{l}\text { The NHIS operators do not } \\
\text { disclose information about } \\
\text { the services covered by their } \\
\text { scheme to the enrollees } \\
\text { until enrollees need such } \\
\text { services. }\end{array}$ & 319 & 4.2163 & 1.40314 & 1.00 & 7.00 & 0.3327883 & $.000^{g}$ \\
\hline INFAS2 & $\begin{array}{l}\text { They do not disclose the } \\
\text { specific service excluded } \\
\text { from the NHIS to enrollees. }\end{array}$ & 319 & 4.2351 & 1.39334 & 1.00 & 7.00 & 0.3289981 & $.000^{8}$ \\
\hline INFAS3 & $\begin{array}{l}\text { They do not disclose to } \\
\text { enrollees the risk covered by } \\
\text { their scheme. }\end{array}$ & 319 & 4.0313 & 1.48545 & 1.00 & 7.00 & 0.3684747 & $.000^{8}$ \\
\hline INFAS4 & $\begin{array}{l}\text { When enrollees need to } \\
\text { be referred to another } \\
\text { NHIS hospital, they do not } \\
\text { disclose to them whether } \\
\text { they need a referral form } \\
\text { or not. }\end{array}$ & 319 & 3.8621 & 1.57209 & 1.00 & 7.00 & 0.4070602 & $.000^{g}$ \\
\hline INFAS5 & $\begin{array}{l}\text { They make enrollees pay } \\
\text { the full cost of the medical } \\
\text { bills in the hospital they are } \\
\text { referred to. }\end{array}$ & 319 & 4.0596 & 1.40738 & 1.00 & 7.00 & 0.3466828 & $.000^{8}$ \\
\hline & INFAS & 319 & 4.0809 & .88202 & 1.80 & 6.60 & 0.2161359 & $.000^{g}$ \\
\hline
\end{tabular}

Source: Authors

disclosure of the information about the NHIS services to the enrollees is moderate. This means that the NHIS service providers partially disclose information to their clients with respect to the services needed.

Table 3 is the moral hazard demonstrated by the enrollees of the NHIS in the selected hospitals. By using the Likert scale ranging from 1 to 7 based on which the enrollees could be assessed, many respondents were indifferent as to whether they were made to pay the full cost of the medical bills if they visited another NHIS hospital in a situation of emergency or not (MORHAZ1: mean/std dev. = 3.6897/1.52369, Coeff. of Var $=0.4129619, \mathrm{p}<0.000$ ). Many NHIS service providers were alleged not to have sufficient drugs in their pharmacies and that simultaneously they failed to refund the cost incurred by enrollees in an emergency situation from other NHIS hospitals. However, many respondents were indifferent to the non-refund of the cost incurred in a situation of emergency (MORHAZ2: mean/std dev. $=4.0909 / 1.52996$, Coeff. of Var $=0.3739893, p<$ 0.000 ) and insufficient drugs in their NHIS hospitals (MORHAZ3: mean/std dev. $=4.2602 / 1.50826$, Coeff. of $\operatorname{Var}=0.3540367, \mathrm{p}<0.000$ ). Additionally, the level of the out-of-pocket expense the respondents were exposed to was moderate (MORHAZ4:mean/std dev. $=4.3041 / 1.67623$, Coeff. of Var $=0.389453, \mathrm{p}<0.000$ ) as a result of their primary healthcare providers not having the necessary equipment or service in place. In order to verify the level of moral hazard amongst the medical doctors and pharmacists in the enrollees' 
Table 3 The demonstration of moral hazard among the NHIS service providers in the selected hospitals

\begin{tabular}{|c|c|c|c|c|c|c|c|c|}
\hline CODES & $\begin{array}{l}\text { Criteria for } \\
\text { moral hazard }\end{array}$ & N & Mean & $\begin{array}{c}\text { Std. } \\
\text { Deviation }\end{array}$ & Minimum & Maximum & $\begin{array}{l}\text { Coeff. } \\
\text { Of Var }\end{array}$ & $\begin{array}{l}\text { Monte } \\
\text { Carlo } \\
\text { Sig. }\end{array}$ \\
\hline MORHAZ1 & $\begin{array}{l}\text { If the enrollees visited } \\
\text { another NHIS hospital in } \\
\text { a situation of emergency, } \\
\text { that hospital which they } \\
\text { are referred to does make } \\
\text { them pay the full cost of } \\
\text { the medical bills. }\end{array}$ & 319 & 3.6897 & 1.52369 & 1.00 & 7.00 & 0.4129619 & $.000^{g}$ \\
\hline MORHAZ2 & $\begin{array}{l}\text { The NHIS usually declines } \\
\text { to refund the medical bills } \\
\text { received in an emergency } \\
\text { service from another } \\
\text { hospital. }\end{array}$ & 319 & 4.0909 & 1.52996 & 1.00 & 7.00 & 0.3739893 & $.000^{8}$ \\
\hline MORHAZ3 & $\begin{array}{l}\text { The NHIS service provider } \\
\text { does not have drugs in its } \\
\text { pharmacy each time you } \\
\text { visit it. }\end{array}$ & 319 & 4.2602 & 1.50826 & 1.00 & 7.00 & 0.3540367 & $.000^{g}$ \\
\hline MORHAZ4 & $\begin{array}{l}\text { Most time, the enrollees } \\
\text { are exposed to an out-of- } \\
\text { pocket expense by having } \\
\text { to pay their medical bills } \\
\text { as a result of their having } \\
\text { received the basic services } \\
\text { provided by the NHIS } \\
\text { service provider. }\end{array}$ & 319 & 4.3041 & 1.67623 & 1.00 & 7.00 & 0.389453 & $.000^{g}$ \\
\hline MORHAZ5 & $\begin{array}{l}\text { The NHIS normally } \\
\text { recommend patients to } \\
\text { their private hospitals for a } \\
\text { specific treatment. }\end{array}$ & 319 & 4.1034 & 1.75512 & 1.00 & 7.00 & 0.4277193 & $.000^{g}$ \\
\hline & MORHAZ & 319 & 4.0897 & 1.06947 & 1.40 & 6.60 & 0.2615055 & $.000^{g}$ \\
\hline
\end{tabular}

Source: Authors

NHIS hospitals, many respondents also indicated a moderate level (MORHAZ5: mean/std dev. = 4.1034/1.75512, Coeff. of Var $=0.4277193, \mathrm{p}<0.000$ ). These responses clearly imply the fact that the level of moral hazard demonstrated by the NHIS service providers was on average moderate since the overall average out of the measurement range significantly fell to 4 (MORHAZ: mean/std dev. $=4.0897 / 1.06947$, Coeff. of Var $=0.2615055, \mathrm{p}<0.000$ ).
Table 4 shows the health-risk behavior expected to be demonstrated by the NHIS enrollees if certain services are not readily available. As can be seen within the scope of the assessment, many were indifferent if they sometimes felt reluctant to visit hospitals when sick, knowing that their NHIS pharmacies do not have drugs (HRB1:mean/std dev. = 3.8025/1.80021, Coeff. of Var $=0.4734265, p<0.000)$, and regarding their opting for buying drugs from a nearby pharmacy rather 
Table 4 Health-risk behavior among the NHIS enrollees in the selected hospitals

\begin{tabular}{|c|c|c|c|c|c|c|c|c|}
\hline CODES & $\begin{array}{c}\text { Criteria for health-risk } \\
\text { behavior }\end{array}$ & $\mathrm{N}$ & Mean & $\begin{array}{c}\text { Std. } \\
\text { Deviation }\end{array}$ & Minimum & Maximum & Coeff. Of Var & $\begin{array}{l}\text { Monte } \\
\text { Carlo Sig. }\end{array}$ \\
\hline HRB1 & $\begin{array}{l}\text { The enrollees sometimes } \\
\text { feel reluctant to visit a } \\
\text { hospital when they are sick } \\
\text { since their NHIS hospitals } \\
\text { do not have drugs in their } \\
\text { pharmacies. }\end{array}$ & 319 & 3.8025 & 1.80021 & 1.00 & 7.00 & 0.4734265 & $.000^{8}$ \\
\hline $\mathrm{HRB} 2$ & $\begin{array}{l}\text { The enrollees would rather } \\
\text { buy drugs from a nearby } \\
\text { pharmacy than waste their } \\
\text { time visiting a hospital. }\end{array}$ & 319 & 4.2257 & 1.84608 & 1.00 & 7.00 & 0.4368694 & $.000^{8}$ \\
\hline $\mathrm{HRB}_{3}$ & $\begin{array}{l}\text { The enrollees would rather } \\
\text { resort to self-medication } \\
\text { than go and waste their } \\
\text { time in a hospital. }\end{array}$ & 319 & 2.4451 & 1.75082 & 1.00 & 7.00 & 0.7160413 & $.000^{8}$ \\
\hline HRB4 & $\begin{array}{l}\text { The services rendered to } \\
\text { the enrollees are not better } \\
\text { than what they can receive } \\
\text { in a nearby pharmacy. }\end{array}$ & 319 & 3.1975 & 1.72346 & 1.00 & 7.00 & 0.5390031 & $.000^{8}$ \\
\hline HRB5 & $\begin{array}{l}\text { It is a waste of time visit } \\
\text { NHIS hospitals when you } \\
\text { know there are no drugs in } \\
\text { their pharmacies. }\end{array}$ & 319 & 3.2915 & 1.70450 & 1.00 & 7.00 & 0.517842 & $.000^{8}$ \\
\hline & HRB & 319 & 3.3737 & 1.14188 & 1.33 & 6.33 & 0.3384626 & $.000^{g}$ \\
\hline
\end{tabular}

Source: Authors

than wasting time visiting the hospital (HRB2:mean/ std dev. $=4.2257 / 1.84608$, Coeff. of Var $=0.4368694, \mathrm{p}$ $<0.000)$. In other words, this means that there is a moderate possibility that the enrollees will not visit a hospital and that they will resort to self-medication. Regarding whether the enrollees would rather resort to self-medication than go and waste their time in hospitals due to moral hazard among their NHIS service providers, many enrollees disagreed upon this particular statement (HRB3:mean/std dev. = 2.4451/1.75082, Coeff. of Var $=0.7160413, p<0.000$ ). This means that, irrespective of any form of moral hazard that may be observed among health workers, this will not discourage the enrollees from using their NHIS scheme. Similarly, many respondents disagreed upon the statement that the services rendered by their NHIS scheme were substandard to what they could receive in a nearby pharmacy (HRB4: mean/std dev. $=3.1975 / 1.72346$, Coeff. of Var $=0.5390031, \mathrm{p}<0.000)$. In respect of the HRB5 criteria, many respondents disagreed that it was a waste of time visiting the NHIS hospitals when you knew that there were no drugs in their pharmacies (HRB5: mean/std dev. = 3.2915/1.70450, Coeff. of Var $=0.517842, \mathrm{p}<0.000$ ). Invariably, the fourth and the fifth criteria indicate the fact that the medical facilities in the selected hospitals are very adequate and that the enrollees' willingness to visit these facilities is very high. However, the overall weight of the health-risk behavior among the enrollees is low (C:mean/std dev. $=3.3737 / 1.14188$, 
Coeff. of Var $=0.3384626, \mathrm{p}<0.000)$ since the overall mean weight obtained from the scale is within the range of $2.5 \leq \mathrm{MW} \leq 3.49$.

\section{Hypotheses Test}

It is often noted that many studies on how information asymmetry and moral hazard by healthcare providers affect service utilization stop at a descriptive level and the evidence of inferential tests are lacking. In this section, the relationships between these variables and the impact as well are tested.

Table 5 shows the relationship between information asymmetry and moral hazard and the health-risk behavior of the NHIS customers. Considering the percentage in which each independent variable contributes to health-risk behavior, the entry of information asymmetry accounts for a $27.3 \%$ increase in health-risk behavior amongst the NHIS enrollees
(INFAS: $(\mathrm{R} 2=0.273 ; \mathrm{F}=118.758, \mathrm{p}<0.05)$. This means that the failure of the healthcare providers to fully disclose information that the NHIS enrollees need to know actually accounts for $27.3 \%$ of why some customers actually engage themselves in healthrisk behavior. Also, the moral hazard demonstrated among the healthcare providers, such as a failure to make drugs available to customers, and referring them to their personal hospitals instead, accounted for $1.5 \%$ of the health-risk behavior amongst the NHIS customers $\left(R^{2}=0.015 ; F=6.836, p<0.05\right)$, thereby increasing the total explained factors from $27.3 \%$ to $28.8 \%$. This means that the combined moral hazard and failure of the NHIS service providers to fully disclose information to customers significantly contributed $28.8 \%$ of the factors leading to health-risk behavior among the enrollees.

Table 6 reveals the direction in which the independent variables of health-risk behavior move. As can be

Table 5 The relationship between moral hazard and information asymmetry and health-risk behavior

\begin{tabular}{c|cccccccccc}
\hline \multirow{2}{*}{ Model } & R & R Square & $\begin{array}{c}\text { Adjusted } \\
\text { R Square }\end{array}$ & $\begin{array}{c}\text { Std. Error } \\
\text { of the } \\
\text { Estimate }\end{array}$ & $\begin{array}{c}\text { R Square } \\
\text { Change }\end{array}$ & F Change & df1 & df2 & $\begin{array}{c}\text { Sig. F } \\
\text { Change }\end{array}$ & $\begin{array}{c}\text { Durbin- } \\
\text { Watson }\end{array}$ \\
\hline 1 & $.522^{\mathrm{a}}$ & .273 & .270 & .97547 & .273 & 118.758 & 1 & 317 & .000 & \\
2 & $.537^{\mathrm{b}}$ & .288 & .283 & .96661 & .015 & 6.836 & 1 & 316 & .009 & 2.049 \\
\hline
\end{tabular}

a. Predictors: (Constant), MORHAZ; b. Predictors: (Constant), MORHAZ, INFAS; c. Dependent Variable: HRBehv Source: Authors

Table 6 The impact of information asymmetry, moral hazard and satisfaction with the service on health-risk behavior

\begin{tabular}{|c|c|c|c|c|c|c|}
\hline & \multirow{2}{*}{ Model } & \multicolumn{2}{|c|}{ Unstandardized Coefficients } & \multirow{2}{*}{$\begin{array}{c}\text { Standardized } \\
\text { Coefficients } \\
\text { Beta }\end{array}$} & \multirow{2}{*}{$\mathrm{t}$} & \multirow{2}{*}{ Sig. } \\
\hline & & B & Std. Error & & & \\
\hline \multirow{2}{*}{1} & (Constant) & 1.094 & .216 & & 5.061 & .000 \\
\hline & MORHAZ & .557 & .051 & .522 & 10.898 & .000 \\
\hline \multirow{3}{*}{2} & (Constant) & .588 & .289 & & 2.038 & .042 \\
\hline & MORHAZ & .511 & .054 & .479 & 9.531 & .000 \\
\hline & INFAS & .170 & .065 & .131 & 2.615 & .009 \\
\hline
\end{tabular}

a. Dependent Variable: HRBehv

Source: Authors 
seen in the table, both moral hazard (MORHAZ: Beta $=0.511, \mathrm{t}=9.531, \mathrm{p}<0.05)$ and information asymmetry (INFAS: Beta $=0.170, t=2.615, p<0.05$ ) have a positive and significant impact on health-risk behavior, which implies that, as the NHIS service providers engage themselves in moral hazard and fail to disclose information, their respective customers are encouraged in one way or another to engage themselves in health-risk behavior. This health-risk behavior is manifested in the form of using alternative means, such as self-medication and the use of nonscientifically proven means to treat themselves, since they know that even if they went to hospitals, their medical needs might not be met well.

\section{Findings Discussion}

The disclosure of information by healthcare providers to clients affects the extent to which clients can utilize health services. This study has examined the influence of information asymmetry and moral hazard on health-risk behavior.

Information disclosure - In order to determine whether information asymmetry is present in the health service providers or not, the five criteria were used to ask for information from the NHIS patients, where the healthcare providers were found to fairly disclose information to their clients and educate them on various services contained in the NHIS, too. Although many clients revealed that their NHIS service providers sometimes made them pay the full cost of the medical bills in the hospital they had been referred to.

Moral hazard - Moral hazard is demonstrated by both the clients and the NHIS service providers. In terms of the incentive to obtain accreditation for participating in the scheme and also for engaging in unethical practices such as requiring that the enrollees should use particular hospitals in a situation of emergency and failing to make drugs available in their respective pharmacies. In order to assess this in the selected hospital, the level of moral hazard in connection with the payment of the full cost of a medical bill and the refunding of these bills in the primary NHIS scheme is moderate. The level of moral hazard in terms of drugs availability and an out-of-pocket expense is also moderate as clients are made to pay for the other services they need outside their respective NHIS. There are mixed responses among the clients to whether medical doctors do recommend them to their personal private hospitals instead of providing such services in the state hospitals they work in.

Health-risk behavior - As far as health-risk behavior following the significant partial disclosure of information and moral hazard is concerned, the implication of this on clients' health-risk behavior was examined. Using the five criteria, it was found that many enrollees of the NHIS sometimes felt reluctant to visit their NHIS hospitals when falling sick due to the observed lack of adequate drugs and vaccines in their NHIS pharmacies. However, according to the information gathered, health-risk behavior following moral hazard and information asymmetry can be said to be low. Also, moral hazard demonstrated among the healthcare providers, such as a failure to make drugs available to customers and referring them to their personal hospitals instead, accounted for merely $1.5 \%$ of health-risk behavior among the NHIS enrollees, thereby increasing the total explained factors from $27.3 \%$ to $28.8 \%$. This means that the combined moral hazard and failure of the NHIS service providers to fully disclose information to the enrollees significantly contributed $28.8 \%$ to the factors leading to health-risk behavior among the enrollees.

\section{CONCLUSION}

Access to quality healthcare is the primary purpose for which the NHIS was introduced. It is believed that the accessibility of the scheme will reduce the enrollees' engagement in health-risk behavior. Due to increasing the non-availability of drugs in most accredited hospitals, particularly so in the public ones, it was speculated that this could lead to the NHIS enrollees' engagement in health-risk behavior. The study shows a pathway to how health insurance can be used to ascertain the excellent treatment seeking behavior of the insured without their engaging themselves in health-risk behavior. The main finding 
shows that $28.8 \%$ of the enrollees' engagement in health-risk behavior is due to moral hazard and asymmetric information demonstrated by the NHIS primary healthcare providers.

Our study is confined to Jos, the capital city of the Plateau State, out of the Nigerian 36 states, which suggests the findings may not adequately reflect the general experience of the NHIS in the country. The study did not establish, either, how the NHIS operational efficiency, asymmetric information and moral hazard affect enrollees' satisfaction. All of these are essentially the limitations of the current study, and there is a need for conducting further studies in order to focus on these limitations. However, the findings of this study contribute to the existing literature in that they investigate the link between the enrollees' health-risk behavior and the moral hazard of the service providers. The findings can also be used to understand the existing bottlenecks in the public hospitals in the studied area and they can be used by the other states of the Federation as well in order to understand how a similar study can be carried out to address the observed health-risk behavior emanating from the moral hazard and asymmetric information of the NHIS primary healthcare providers.

\section{REFERENCES}

Adeyele, J. S. (2014). Civil servants' lifestyle and health care use pattern: Evidence from Akure Metropolis. African Journal of Institutions and Development, 9(1\&2), 416-422.

Al-Arifi, M. N. (2012). Patients' perception, views and satisfaction with pharmacists' role as health care provider in community pharmacy setting at Riyadh, Saudi Arabia. Saudi Pharmaceutical Journal, 20(4), 323-330. doi:10.1016/j. jsps.2012.05.007

Albert, M. C., \& Riordan, M. H. (2002). Health insurance, moral hazard, and managed care. Journal of Economics \& Management Strategy, 11(1), 81-107. doi.org/10.1111/j.14309134.2002.00081.x
Baban, A., \& Craciun, C. (2007). Changing health-risk behaviours: A review of theory and evidence-based interventions in health psychology. Journal of Cognitive and Behavioural Psychology, 7(1), 45-66.

Berman, P., Pallas, S., Smith, A. L., Curry, L., \& Bradley, E. H. (2011). Improving the delivery of health services: A guide to choosing strategies. Washington DC, W: The International Bank for Reconstruction and Development/The World Bank

Black, U., \& Skipper, H. D. (2000). Life and Health Insurance. Delhi: Pearson Education, Inc.

Carlstrom, C. T. (June 1, 1994). The government's role in the health care industry: past, present, and future. Federal Reserve Bank of Cleveland Economic Commentary.

Doherty, N. A., \& Smetters, K. (2005). Moral hazard in reinsurance markets. Journal of Risk and Insurance, 72(3), 375391. doi.org/10.1111/j.1539-6975.2005.00129.x

Garven, J. R., \& Grace, M. F. (2007). Adverse selection in reinsurance market. Paper presented at American Risk and Insurance Association 2007 annual meeting.

Iversen, T. (1993). A Theory of hospital waiting lists. Journal of Health Economics, 12(1), 55-71. doi.org/10.1016/01676296(93)90040-L

Jean-Baptiste, E. L., \& Santomero, A. M. (2000). The design of private reinsurance contracts. Journal of Financial Intermediation, 9(3), 274-297. doi:10.1006/fin.2000.0291

Konetzka, R. T., He, D., Guo, J., \& Nyman, J. A. (2019). Moral hazard and long-term care insurance. Geneva Papers on Risk and Insurance: Issues and Practice, 44(2), 231-251. doi. org/10.1057/s41288-018-00119-1

Laschinger, H. S., Hall, L. M., Pedersen, C., \& Almost, J. (2005). A psychometric analysis of the patient satisfaction with nursing care quality questionnaire: an actionable approach to measuring patient satisfaction. Journal of Nursing Care Quality, 20(3), 220-230.

Marquez-Peiro, J. F., \& Perez-Peiro, C. (2008). Evaluation of patient satisfaction in outpatient pharmacy. Farmacia Hospitalaria, 32(2), 71-76. doi:10.1016/s2173-5085(08)70029-7

Ndukwe, H. C., Omale, S., \& Opanuga, O. O. (2011). Reducing queues in a Nigerian hospital pharmacy. African Journal off pharmacy and farmacology, 5(8), 1020-1026. doi:10.5897/ ajpp11.015 
Shavell, S. (1979). On Moral Hazard and Insurance. The Quarterly Journal of Economics, 93(4), 541-562. doi. org/10.2307/1884469

Shmanske, S. (1996). Information asymmetries in health services: The market can cope. The Independent Review, 1(2), 191-200.
Steptoe, A., \& Wardle, J. (2004). Health-related behaviour: Prevalence and links with disease. In A. Kaptein, \& J. Weinmen (Eds.). Health Psychology (pp. 21-51). Malden, USA: Blackwell Publishing.

Zeckhauser, R. (1970). Medical Insurance: A case study of the tradeoff between risk spreading and appropriate incentives. Journal of Economic Theory, 2(1), 10-26. doi.org/10.1016/00220531(70)90010-4

Received on $7^{\text {th }}$ Jun 2019, after revision, accepted for publication on $20^{\text {th }}$ August 2019 Published online on $23^{\text {rd }}$ August 2019

Joshua Solomon Adeyele is a lecturer at the Department of Actuarial Science; University of Jos. He obtained his PhD degree at the University of Ilorin. Dr. Adeyele is an Associate of Chartered Insurance Institute, Nigeria (CIIN) and a member of Academy of Management Nigeria (MAMN). The most significant areas of his scientific research interest and work are: Pension Funds, Risk modeling and Enterprise risk management, Survival models, health care modeling.

Gbenga Michael Ogungbenle is a lecturer at the Department of Actuarial Science, University of Jos. He has master degrees in Mathematics and Actuarial Science both from University of Lagos, Nigeria. The most significant areas of his scientific research and interest are Actuarial modeling, Pension valuation and Mathematical methods.

Ogorchukwu Augustine Isimoya is a senior lecturer at the Department of Actuarial Science and Insurance, University of Lagos, Akoka-Lagos, where he obtained his $\mathrm{PhD}$ in 2018. He teaches Introduction and Principles of Insurance, Property Insurance, Marketing of Insurance Services at undergraduate level, Enterprise risk Management (ERM) and Corporate governance at Masters' degree level. 


\title{
ASIMETRIČNE INFORMACIJE I PONAŠANJE RIZIČNO PO ZDRAVLJE U NACIONALNOM PROGRAMU ZDRAVSTVENOG OSIGURANJA U METROPOLI DŽOS, NIGERIJA
}

\author{
Joshua Solomon Adeyele ${ }^{1}$, Gbenga Michael Ogungbenle ${ }^{1}$ and \\ Ogorchukwu Augustine Isimoya² \\ 'Department of Actuarial Science, University of Jos, Nigeria \\ 2Department of Actuarial Science and Insurance, University of Lagos, Lagos, Nigeria
}

\begin{abstract}
Omogućavanje pristupa kvalitetnoj zdravstvenoj nezi predstavlja primarnu svrhu u koju je i bio uveden nacionalni program zdravstvenog osiguranja (NPZO) u Nigeriji. Veruje se da će uvođenje NPZO za radnike njihovu smanjiti sklonost ka modalitetima ponašanja rizičnim po zdravlje. Uprkos činjenici da NPZO postoji, osiguranici (osigurani radnici) se još uvek žale na lošu uslugu zdravstvene nege, koju dobijaju od pružalaca te usluge. Kao rezultat toga, neki još uvek pokazuju sklonost ka škodljivom ponašanju rizičnom po zdravlje, zbog moralnog hazarda prisutnog kod radnika u sektoru javne zdravstvene nege, kao i zbog nedostatka lekova u javnim bolnicama. Ova studija je sprovedena u metropoli Džos, kako bismo utvrdili u kojoj meri moralni hazard i aimetrične informacije o NPZO vode ka ponašanju rizičnom po zdravlje među državnim službenicima. Sprovedeno istraživanje je pokazalo da postoji umereni nivo moralnog hazarda na strani pružalaca usluga u okviru NPZO, pošto na mernoj skali od 1 do 7 sveukupni prosek značajno ima vrednost 4 od maksimalno 7. Suprotno umerenom nivou moralnog hazarda prisutnog na strani pružalaca usluga NPZO, došlo se do saznanja da najveći broj osiguranika NPZO u proseku ispoljava sklonost ka ponašanju sa niskim rizikom po zdravlje.
\end{abstract}

Ključne reči: pružaoci usluga NPZO, moralni hazard, asimetrične informacije, ponašanje rizično po zdravlje

JEL Classification: D82, I11, I13 